\title{
Article \\ Adsorption of Recombinant Human $\beta$-Defensin 2 and Two Mutants on Mesoporous Silica Nanoparticles and Its Effect against Clavibacter michiganensis subsp. michiganensis
}

\author{
Gabriel Marcelino-Pérez ${ }^{1}$ (), Roberto Ruiz-Medrano ${ }^{2}$, Salvador Gallardo-Hernández ${ }^{3, *}$ \\ and Beatriz Xoconostle-Cázares ${ }^{2, *}$ \\ 1 Programa de Doctorado en Nanociencias y Nanotecnología, Centro de Investigación y de Estudios \\ Avanzados del Instituto Politécnico Nacional, Av. IPN 2508, Ciudad de México 07360, Mexico; \\ gabriel.marcelino@cinvestav.mx \\ 2 Departamento de Biotecnología y Bioingeniería, Centro de Investigación y de Estudios Avanzados del \\ Instituto Politécnico Nacional, Av. IPN 2508, Ciudad de México 07360, Mexico; rmedrano@cinvestav.mx \\ 3 Departamento de Física, Centro de Investigación y de Estudios Avanzados del Instituto Politécnico Nacional, \\ Av. IPN 2508, Ciudad de México 07360, Mexico \\ * Correspondence: sgallardo@fis.cinvestav.mx (S.G.-H.); bxoconos@cinvestav.mx (B.X.-C.)
}

Citation: Marcelino-Pérez, G.; Ruiz-Medrano, R.;

Gallardo-Hernández, S.;

Xoconostle-Cázares, B. Adsorption of

Recombinant Human $\beta$-Defensin 2

and Two Mutants on Mesoporous

Silica Nanoparticles and Its Effect against Clavibacter michiganensis subsp. michiganensis. Nanomaterials 2021, 11, 2144. https://doi.org/ 10.3390/nano11082144

Academic Editor: Daniela Iannazzo

Received: 17 July 2021

Accepted: 14 August 2021

Published: 23 August 2021

Publisher's Note: MDPI stays neutral with regard to jurisdictional claims in published maps and institutional affiliations.

Copyright: (c) 2021 by the authors. Licensee MDPI, Basel, Switzerland. This article is an open access article distributed under the terms and conditions of the Creative Commons Attribution (CC BY) license (https:// creativecommons.org/licenses/by/ $4.0 /)$.
Abstract: Solanum lycopersicum L. is affected among other pests and diseases, by the actinomycete Clavibacter michiganensis subsp. michiganensis $(\mathrm{Cmm})$, causing important economic losses worldwide. Antimicrobial peptides (AMPs) are amphipathic cationic oligopeptides with which the development of pathogenic microorganisms has been inhibited. Therefore, in this study, we evaluate antimicrobial activity of mesoporous silica nanoparticles (MSN5.4) loaded with human $\beta$-defensin-2 (h $\beta$ D2) and two mutants (TRX-h $\beta \mathrm{D} 2-\mathrm{M}$ and $\mathrm{h} \beta \mathrm{D} 2-\mathrm{M}$ ) against $\mathrm{Cmm}$. $\mathrm{h} \beta \mathrm{D} 2$, TRX-h $\beta \mathrm{D} 2-\mathrm{M}$ and $\mathrm{h} \beta \mathrm{D} 2-\mathrm{M}$ presented a half-maximum inhibitory concentration $\left(\mathrm{IC}_{50}\right)$ of $3.64,1.56$ and $6.17 \mu \mathrm{g} / \mathrm{mL}$, respectively. MSNs had average particle sizes of $140 \mathrm{~nm}$ (SEM) and a tunable pore diameter of 4.8 up to $5.4 \mathrm{~nm}(\mathrm{BJH})$. AMPs were adsorbed more than $99 \%$ into MSN and a first release after $24 \mathrm{~h}$ was observed. The MSN loaded with the AMPs inhibited the growth of $\mathrm{Cmm}$ in solid and liquid media. It was also determined that MSNs protect AMPs from enzymatic degradation when the MSN/AMPs complexes were exposed to a pepsin treatment. An improved AMP performance was registered when it was adsorbed in the mesoporous matrix. The present study could expand the applications of MSNs loaded with AMPs as a biological control and provide new tools for the management of phytopathogenic microorganisms.

Keywords: mesoporous silica nanoparticles; antimicrobial peptides; human $\beta$-defensin-2; peptide adsorption; peptide release

\section{Introduction}

One of the most important crops worldwide is tomato, the fruit of S. lycopersicum L., of which just in 2019 production exceeded 180 million tons [1]. Depending on the growth stage and environmental conditions, this crop can be negatively affected by stress, pests and diseases that not only cause damage to the stem and fruit, but also to the root system of the plant $[2,3]$. Cmm is a Gram-positive bacterium distributed worldwide that causes bacterial tomato canker disease, which can cause large economic losses to farmers if not treated properly and in a timely manner [4]. The use of contaminated seeds and asymptomatic transplants causes the propagation of the disease, detection methods are inefficient at differentiating C $\mathrm{mm}$ from non-pathogenic Clavibacter strains [5]. However, the possibility exists to make detection methods more efficient by merging emerging and mature technologies. For example, the detection of pathogenic microorganisms by means of antibodies functionalized to nanomaterials [6]. The infection occurs in seeds at early stages or young seedlings. When infection occurs in adult plants it could be asymptomatic, eventually producing marketable fruits $[4,7,8]$. Depending on the climatic conditions and 
geographical position, $\mathrm{Cmm}$ can survive inside contaminated seeds and plant residues for months or even years $[9,10]$.

Currently the control of $\mathrm{Cmm}$ and other diseases are based mainly on application of chemical pesticides $[7,11]$. However, their indiscriminate use has shown side effects such as high-water quality requirements for irrigation, reduction of fruit quality, soil erosion, dangers to both human and environmental health and mainly the development of pathogen resistance [2,12]. Other eco-friendlier alternatives have been proposed for the control of $\mathrm{Cmm}$, among which the application of inorganic nanomaterials with antimicrobial activity such as nanoparticles (NPs) of $\mathrm{Ag}, \mathrm{ZnO}, \mathrm{Cu}$, etc., the biological control (competition between microorganisms), the introduction of resistant cultivars and the direct application of biomolecules with antimicrobial activity to cultivars [13-15]. Defensins are relatively short amphipathic cationic oligopeptides with variable length, sequence and structures that protect their host from a wide variety of bacteria, fungi and viruses [16]. They are usually composed of 5-100 amino acid residues, characterized by having 6-8 cysteine residues that link together to give rise to the formation of disulfide bridges [16-19]. According to the disposition of their disulfide bridges, defensins are subdivided into three different subfamilies: $\alpha$-defensins, $\beta$-defensins and $\theta$-defensins [17]. Specifically, $\mathrm{h} \beta \mathrm{D} 2$ is composed of 41 amino acid residues and as the other $\beta$-defensins bears a 6-cysteine motif to be stabilized by three conserved disulfide bridges; $\mathrm{h} \beta \mathrm{D} 2$ antimicrobial activity has been evaluated against different human pathogenic strains such as Actinobacillus actinomycetemcomitans, Candida albicans and Pseudomona aeruginosa $[19,20]$. The exact mechanism by which $\mathrm{h} \beta \mathrm{D} 2$ exhibits antimicrobial activity is unknown, however, thanks to the resolution of its atomic structure by means of $\mathrm{X}$-ray diffraction, it has been hypothesized that the uniform surface distribution of positively charged residues allow $\mathrm{h} \beta \mathrm{D} 2$ to interfere with the cell walls of bacteria by means of electrostatic interactions with the polar head groups of the wall, such as lipopolysaccharides (Gram-negative bacteria) and teichoic acids (Gram-positive bacteria) $[16,17,21-24]$. Despite their mentioned great properties, these biomolecules exhibit different drawbacks such as susceptibility to proteases, the fact the their activity is reduced at high salt concentrations, changes in $\mathrm{pH}$ and temperature and at concentrations above $10 \mu \mathrm{g} / \mathrm{mL}$ tend to produce pro-inflammatory effects on humans [25]. An alternative that has been proposed to avoid the aforementioned effects is to encapsulate the AMPs [26].

The matrix of the nanocapsules can be constructed from proteins, polysaccharides and synthetic polymers [27]. Mesoporous silica-based materials have been gaining ground in recent years; structural characteristics such as uniform distribution of pore size, high specific surface area, high pore volume and tunable pore size $(2-50 \mathrm{~nm})$ make them excellent candidates for the encapsulation and delivery of biologically active molecules [28,29]. The main advantages of adsorbing biomolecules within a mesoporous matrix are their protection against adverse factors that cause their degradation and when they are released, they do so in a controlled manner at specific sites [30]. Different studies have shown that biomolecules that are released in a controlled and gradual manner have greater reactivity compared to those that are not found within a mesoporous matrix [31-33]. Thanks to this property, it has also been possible to expand the application of drugs or biomolecules that in high concentrations were considered toxic or produced cytotoxic effects (AMPs) [30]. In this context, the present work aimed to synthesize MSN, to encapsulate recombinant h $\beta D 2$ and two mutants and to evaluate their antimicrobial activity against phytopathogenic bacteria $\mathrm{Cmm}$.

\section{Materials and Methods}

\subsection{Reagents}

N,N-dimethylhexadecylamine (DHMA, $\geq 95 \%$, Sigma Aldrich, Saint Louis, MO, USA), Pluronic F127 (EO106PO70EO106, Mw = 12600, Sigma Aldrich), cetyltrimelammonium bromide (CTAB, $\geq 95 \%$, Sigma Aldrich), $\mathrm{NaOH}$ (Macron Fine Chemicals, Radnor, PA, USA), tetraethyl orthosilicate (TEOS, $\geq 99 \%$, Sigma Aldrich), anhydrous glycerol (J.T. Baker, Radnor, PA, USA), glucose ( $\geq 99.5 \%$, Sigma Aldrich), imidazole (99\%, Sigma Aldrich), Tris base 
(Tris, $\geq 99.8 \%$, J.T. Baker), $\mathrm{KH}_{2} \mathrm{PO}_{4}$ ( $\geq 95 \%$, High Purity, Santiago de Querétaro, QRO, Mexico), $\mathrm{K}_{2} \mathrm{HPO}_{4}$ ( $\geq 98 \%$, Sigma Aldrich), $\mathrm{NaCl}$ ( $\geq 99 \%$, J.T. Baker), pepsin from porcine gastric mucosa (Sigma Aldrich), yeast extract (DIBICO, Cuautitlán Izcalli, EDOMÉX, Mexico) and casein peptone (DIBICO). For the synthesis of MSN, deionized water with a resistivity of 18.2 $\mathrm{M} \Omega \bullet \mathrm{cm}$ was used. For all other experiments double distilled water was employed.

\subsection{Plasmids}

The amino acid sequence of $\mathrm{h} \beta \mathrm{D} 2$ was obtained from the Protein Data Bank (1FD3). The sequence of the gene that codes for $\mathrm{h} \beta \mathrm{D} 2$ with optimized codons for Escherichia coli was cloned between the restriction sites NcoI and XhoI within the vector pUC57 (pUC57$\mathrm{h} \beta \mathrm{D} 2$ ) by the company GenScript. The plasmid was reconstituted within Milli-Q water and transformed into chemocompetent E. coli Mach1 T1 cells. Subsequently, pUC57-h $\beta D 2$ and the expression vector pCri-4a extracted with the commercial kit ZR Plasmid MiniprepClassic (Zymo Research, Tustin, CA, USA) were subjected to a double restriction assay with the enzymes NcoI and XhoI. The restricted products $\mathrm{h} \beta \mathrm{D} 2$ and pCri-4a were purified from with the Zymoclean Gel DNA Recovery Kit (Zymo Research) from a 1\% agarose gel and ligated together with the enzyme T4 DNA Ligase. Chemically competent cells of $E$. coli Mach1 T1 were transformed with the pCri-4a-h $\beta \mathrm{D} 2$ construction. Recombinant plasmids were sequenced in both directions. The expression vector pCri-4a allows the expression of a translated fusion to a 6-histidine tag, followed by sequence encoding to the thioredoxin-binding protein (TrxA) and contain a tobacco etch virus protease (TEV) cleavage site (Figure 1A). In order to improve the intrinsic activity of h $\beta D 2$ [34], a directed mutagenesis was carried out, incorporating a glycine residue at the amino terminal end and an arginine residue at the carboxyl end (TrxA-h $\beta \mathrm{D} 2-\mathrm{M})$.

\subsection{Expression of TRX-h $\beta D 2$ and $\operatorname{Tr} x A-h \beta D 2-M$}

E. coli Rosetta (DE3) previously transformed with the plasmid pCri-4a-h $\beta \mathrm{D} 2$ or pCri$\mathrm{h} \beta \mathrm{D} 2-\mathrm{M}$ was seeded in $50 \mathrm{~mL}$ lysogeny broth (LB,) supplemented with kanamycin sulfate $(50 \mu \mathrm{g} / \mathrm{mL})$, chloramphenicol $(20 \mu \mathrm{g} / \mathrm{mL})$ and glucose $(5 \mathrm{~g} / \mathrm{L})$. The culture was incubated at $37^{\circ} \mathrm{C}$ for $16 \mathrm{~h}$ at $180 \mathrm{rpm}$ for $16 \mathrm{~h}$. $4 \mathrm{~L}$ of Terrific Broth medium (peptone $12 \mathrm{~g} / \mathrm{L}$, yeast extract $24 \mathrm{~g} / \mathrm{L}, \mathrm{K}_{2} \mathrm{HPO}_{4} 9.4 \mathrm{~g} / \mathrm{L}, \mathrm{KH}_{2} \mathrm{PO}_{4} \mathrm{~g} / \mathrm{L}$, glycerol $\left.4 \mathrm{~mL} / \mathrm{L}\right)$ supplemented with the same antibiotics and sugar mentioned above were inoculated with $1 \%$ from the preinoculum. The cultures were kept under a constant temperature $\left(37^{\circ} \mathrm{C}\right)$ and shaking $(200 \mathrm{rpm})$ until the $\mathrm{OD}_{600}$ reached $0.7-0.8$. The expression of the fusion proteins was induced with $1 \mathrm{mM}$ isopropyl $\beta$-d-galactopyranoside (IPTG). After carrying out the induction, the culture was incubated at $18{ }^{\circ} \mathrm{C}$ for $16 \mathrm{~h}$ at $150 \mathrm{rpm}$. The cells were harvested by centrifugation at $5000 \times g$ for $30 \mathrm{~min}$ at $4{ }^{\circ} \mathrm{C}$ and stored at $-80^{\circ} \mathrm{C}$ until protein extraction.

\subsection{Purification of TRX-h $\beta D 2$ and $\operatorname{Tr} x A-h \beta D 2-M$}

Cell pellets (approximately $15 \mathrm{~g})$ were resuspended in buffer A (20 mM NaH $\mathrm{PO}_{4}$, $0.5 \mathrm{M} \mathrm{NaCl}, 20 \mathrm{mM}$ imidazole, $\mathrm{pH}$ 7.4) and then lysed by sonication within an ice bath using the Ultrasonic Homogenizer 750 (Cole-Parmer, Vernon Hills, IL, USA). The cell lysate was centrifuged at $164,391 \times g$ for $30 \mathrm{~min}$ at $4{ }^{\circ} \mathrm{C}$. The supernatant obtained loaded on a HisTrap HP $5 \mathrm{~mL}$ column previously equilibrated with buffer A. Proteins were eluted through a linear gradient (1-100\%) with buffer $\mathrm{B}\left(\mathrm{NaH}_{2} \mathrm{PO}_{4} 20 \mathrm{mM}, 0.5 \mathrm{M} \mathrm{NaCl}, 500 \mathrm{mM}\right.$ imidazole, $\mathrm{pH}$ 7.4) for $15 \mathrm{CV}$, the fusion proteins were resolved in $10 \%$ Tricine-SDS-PAGE. To carry out the cleavage of the fusion proteins by TEV protease, the eluted fractions containing the protein of interest were subjected to a buffer exchange from $B$ to $C$ ( $1 \mathrm{mM}$ reduced glutathione, $25 \mathrm{mM}$ Tris- $\mathrm{HCl}, 150 \mathrm{mM} \mathrm{NaCl}, \mathrm{pH}$ 7.4) using a HiPrep 26/10 Desalting column. The desalted fractions were mixed and the TEV enzyme was added in a ratio of $1: 100 \mathrm{v} / \mathrm{v}$, the reaction mixture was incubated at $4{ }^{\circ} \mathrm{C}$ for $16 \mathrm{~h}$. After cleavage process, the samples were re-purified using a HisTrap HP column using the previously mentioned conditions. The proteins that did not bound to the column, (corresponding to the AMPs) were concentrated to $0.5 \mathrm{~mL}$ with a centrifugal concentrator with a $3 \mathrm{kDa}$ cut-off. To 
determine the concentration and yield of total protein in each of the purification processes, a commercial Pierce ${ }^{\mathrm{TM}}$ BCA ${ }^{\mathrm{TM}}$ kit (ThermoFisher Scientific, Rockford, IL, USA) was used.

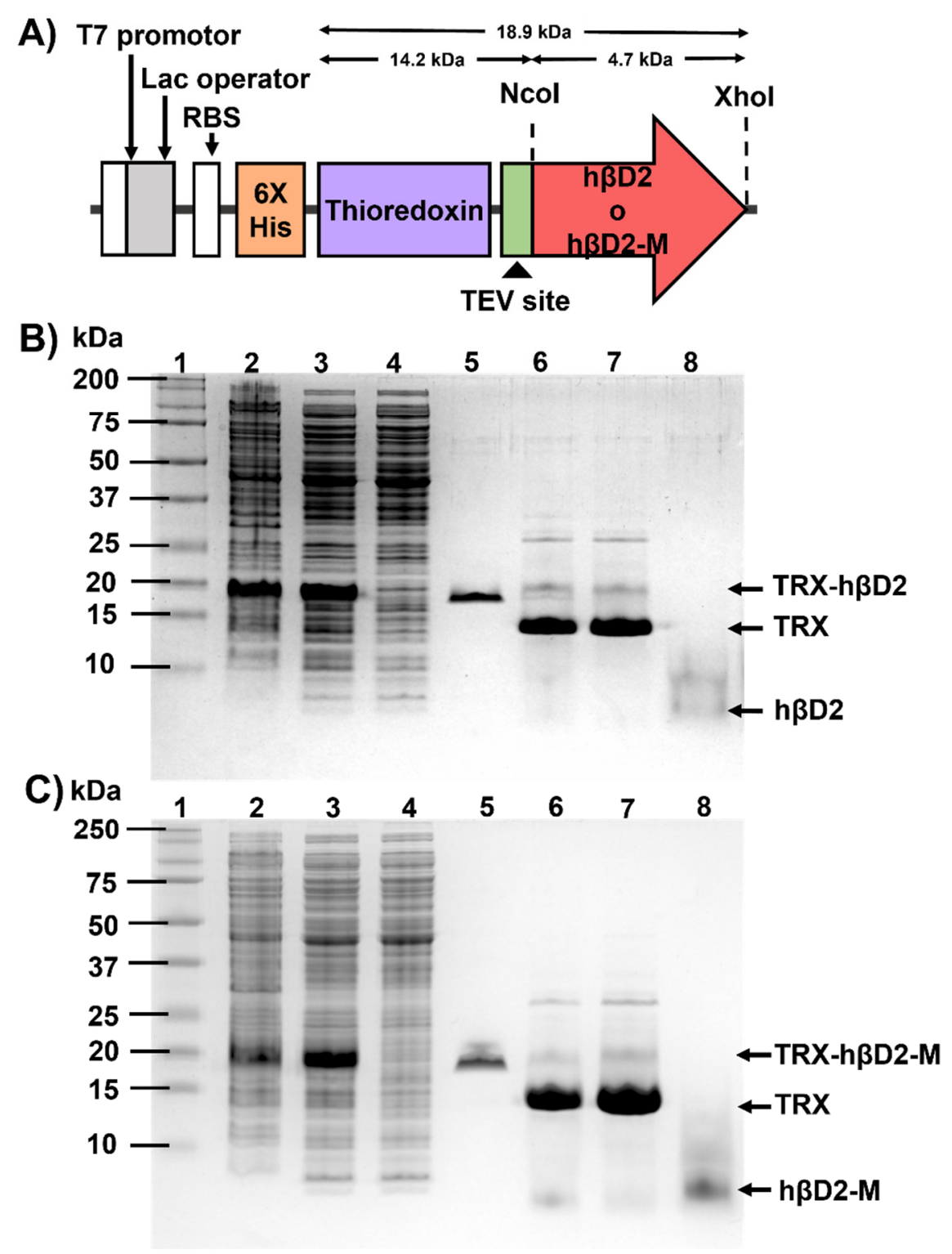

Figure 1. Construction, expression and purification of recombinant proteins. (A) Schematic representation of the reading frame of the expression vector TRX-h $\beta \mathrm{D} 2$ and TRX-h $\beta \mathrm{D} 2-\mathrm{M},(\mathbf{B})$ expression and purification of $\mathrm{h} \beta \mathrm{D} 2$; lane 1: molecular weight marker, lane 2: insoluble fraction, lane 3: soluble fraction, lane 4: fraction not bound to the first $\mathrm{Ni}^{2+}$-IMAC purification step, lane 5: fraction bound to the first $\mathrm{Ni}^{2+}$-IMAC purification step, lane 6: fraction after cleavage by TEV protease, lane 7: fraction bound to the second purification step by $\mathrm{Ni}^{2+}$-IMAC and lane 8: fraction not bound to the second purification step by $\mathrm{Ni}^{2+}$-IMAC. (C) expression and purification of $\mathrm{h} \beta \mathrm{D} 2-\mathrm{M}$; the charging plan is the same as for $h \beta D 2$.

\subsection{Synthesis of Mesoporous Silica Nanoparticles (MSN)}

The MSNs were synthesized based on the reported by Gu et al. [35], with the following modifications for increasing the pore diameter (Table S1). The synthesis of MSN carried out in this work is based on the self-assembly of negatively charged silicates (TEOS) and micelles composed of positively charged CTAB and DMHA under basic $\mathrm{pH}$ conditions, where F127 acts as a size inhibitor and dispersing agent to the same time by encapsulating the previous complex. The method is as follows: Treatment 1: at $22-25^{\circ} \mathrm{C} 0.5 \mathrm{~g}$ CTAB 
(structure directing agent) and $50 \mathrm{mg}$ of F127 were dissolved on $0.4 \mathrm{~mL}$ DHMA. Deionized water $(240 \mathrm{~mL})$ and $2 \mathrm{M} \mathrm{NaOH}(1.75 \mathrm{~mL})$ were added to the mixture by vigorous stirring (600 rpm). After the solution becomes clarified, it was transferred to a flat-bottomed flask where the temperature was increased to $80^{\circ} \mathrm{C}$. Once the temperature was stabilized, $2.5 \mathrm{~mL}$ of TEOS was added dropwise and the flask was refluxed by maintaining the same temperature and stirring conditions for $2 \mathrm{~h}$. At the end, the reaction mixture was cooled to room temperature and MSNs were concentrated and washed with ethanol once and water twice by centrifugation. To remove the surfactant template, $1 \mathrm{~g}$ of the material obtained was dissolved within an ethanol solution acidified with hydrochloric acid ( $1 \mathrm{~mL}$ of $37 \%$ $\mathrm{HCl}$ and $100 \mathrm{~mL}$ of absolute ethanol) and refluxed at $80^{\circ} \mathrm{C}$ for $24 \mathrm{~h}$ to $600 \mathrm{rpm}$. The MSNs were concentrated and washed again by centrifugation with methanol twice. The material obtained was dried at $50{ }^{\circ} \mathrm{C}$ for $16 \mathrm{~h}$ and stored for further use.

\subsection{MSN Characterization}

The particle size distribution of the NPs was determined by dynamic light scattering (DLS) with a Zetasizer Nano ZSP (Malvern Panalytical, Malvern, UK). To find out the possible functional groups of the material under study, Fourier transform infrared spectroscopy (FT-IR) was performed using an infrared spectrophotometer Nicolet 6700 (Thermo Electron Scientific Instruments Corporation, Madison, WI, USA). Raman spectroscopy was used to determine the different vibrational modes of the MSN, for this analysis the AFM-Raman NTEGRA SPECTRA II system (NT-MDT, Moscow, Russia) was used using a blue solid-state laser $(455 \mathrm{~nm})$. The analyses were carried out at room temperature by scanning a range of 200-1400 nm in the Raman shift. The morphology, size and porosity of the MSN were determined by transmission electron microscopy (TEM) and scanning (SEM). The samples for TEM were visualized in a JEM 2010 transmission electron microscope (JEOL, Peabody, MA, USA) using an acceleration of $200 \mathrm{KV}$. The samples were also observed in an AURIGA 3916-FESEM scanning electron microscope (CARL ZEISS, Jena, Germany) using an acceleration of $2 \mathrm{KV}$. The nitrogen adsorption-desorption isotherms of MSN were obtained using a Minisorb II instrument (BEL, Osaka, Japan) at $77 \mathrm{~K}$. Prior to analysis, the samples were degassed at room temperature for $24 \mathrm{~h}$. Specific surface areas were determined based on adsorption data using the Brunauer-Emmett-Teller (BET) model whilefrom the branches of the desorption isotherms and using the Barret-Joyner-Halenda (BJH) model, the effective volume and size distributions of pores were determined. Finally, the total pore volume was calculated based on the amount of $\mathrm{N}_{2}$ absorbed at a relative pressure $\left(\mathrm{P} / \mathrm{P}_{0}\right)$ of 0.99 .

\subsection{Antimicrobial Activity Assay and Determination of $I_{50}$}

$\mathrm{Cmm}$ was cultivated in Mueller-Hinton broth (MHB) at $37^{\circ} \mathrm{C}$ for $16 \mathrm{~h}$ at $180 \mathrm{rpm}$. Employing $0.5 \mathrm{~mL}$ of the previous culture, $50 \mathrm{~mL}$ of fresh $\mathrm{MHB}$ were inoculated. The culture was maintained under the conditions mentioned above until the $\mathrm{OD}_{600}$ reached 0.2-0.3. $9.5 \mathrm{~mL}$ of $\mathrm{MHB}$ agar prewarmed to $37^{\circ} \mathrm{C}$ were added to $0.5 \mathrm{~mL}$ of the culture. It was homogenized and then poured onto a Petri dish containing MHB agar to form a uniform layer of $2 \mathrm{~mm}$. Once the surface was dry, different volumes $(5,10$ and $15 \mu \mathrm{L})$ of the defensins under study $(50 \mu \mathrm{M})$ were added to the surface. The plates were incubated for $24 \mathrm{~h}$ at $28{ }^{\circ} \mathrm{C}$, then the formed inhibition halos were measured. $\mathrm{CH}_{3} \mathrm{COOH}$ (acid acetic) $10 \mathrm{mM}$ pH 2.4 and Tris $50 \mathrm{mM} \mathrm{pH} 8.4$ were used both as negative controls. The $\mathrm{IC}_{50}$ was determined based on that reported by Tay and Liu [36,37]. This measurement was defined as the minimum concentration of AMP that is required to inhibit $50 \%$ of the growth of Cmm.

\subsection{Adsorption/Release of AMPs by MSN5.4}

A microtube were filled with $5 \mathrm{mg}$ of MSN5.4 (previously sterilized by UV light), $0.5 \mathrm{mg}$ of AMPs and an amount of PBS $67 \mathrm{mM} \mathrm{pH} 7.0$ to complete a final volume of $1 \mathrm{~mL}$. The mixture was kept under constant stirring for $16 \mathrm{~h}$ at $4{ }^{\circ} \mathrm{C}$. The samples were centrifuged at $10,000 \times g$ for $15 \mathrm{~min}$ at $4^{\circ} \mathrm{C}$ at the end of the incubation period. The 
supernatant was carefully removed and analyzed by the Pierce ${ }^{\mathrm{TM}}$ BCA Protein kit to determine the percentage of total protein concentration and thus indirectly estimate the adsorption of AMPs by MSN5.4. AMPs in PBS at the same concentration were used as controls.

About the release of AMPs, the methodology referred to in the previous paragraph was re-performed. The removal of the supernatant was done, and the pellet was dried in sterile conditions for $2 \mathrm{~h}$. After $1 \mathrm{~mL}$ of sterilized PBS was added to the pellet and shaken with the aid of a vortex to obtain a homogeneous mixture, the microtubes remained at constant agitation and temperature $28 \pm 2{ }^{\circ} \mathrm{C}$ throughout the whole analysis period plotted $(2,6,24,48,72,96,120,144,168,192$ and 216 h). For each sampling point, microtubes were centrifuged at $10,000 \times g$ for $15 \mathrm{~min}$ at $4{ }^{\circ} \mathrm{C}$, the resulting pellet was resuspended in $1 \mathrm{~mL}$ of sterile PBS. Supernatants were kept being analyzed by the Pierce ${ }^{\mathrm{TM}}$ BCA Protein kit (Thermo Fisher, Rockford, IL, USA) to determine the total protein concentration that was being released. These experiments were performed by triplicates.

\subsection{Antimicrobial Activity of MSN/AMPs Complexes}

The antimicrobial activity of the MSN/AMPs complexes was evaluated both in solid and liquid media. For the solid medium, the adsorption process was carried out as described in the previous section. The pellet was resuspended in PBS $(1 \mathrm{~mL})$. Afterwards, different volumes of the MSN/AMPs mixture were deposited onto Petri dishes with MHB medium and $\mathrm{Cmm}$ (see antimicrobial activity test section and $\mathrm{IC}_{50}$ determination). The plates were incubated for $24 \mathrm{~h}$ at $28^{\circ} \mathrm{C}$, the diameter of the inhibition halos was measured. MSN $(5 \mathrm{mg} / \mathrm{mL})$ and AMPs $(0.5 \mathrm{mg} / \mathrm{mL})$ were employed as controls. These experiments were performed by triplicates.

To evaluate the antimicrobial activity of the MSN/AMPs complexes at liquid medium, a $\mathrm{Cmm}$ preinoculum was first placed on MHB medium and incubated at $28^{\circ} \mathrm{C}$ for $24 \mathrm{~h}$ at $180 \mathrm{rpm}$. Cells were inoculated to MHB medium in proportion 1:100 $v / v$ and kept under the same conditions until the $\mathrm{OD}_{600}$ reached 0.5. From the previous culture, $200 \mu \mathrm{L}$ were taken and added to $40 \mathrm{~mL}$ of fresh MHB medium to have a cell concentration of $2.5 \times 10^{6}$ colony forming units per $\mathrm{mL}(\mathrm{CFU} / \mathrm{mL})$; this was referred as the "diluted culture". To set the adsorption process of the AMPs by MSN, after removing the supernatant and drying the MSN/AMPs, complexes were resuspended in $3 \mathrm{~mL}$ of diluted $\mathrm{Cmm}$ culture and incubated at $28{ }^{\circ} \mathrm{C}$ for $24 \mathrm{~h}$ at $180 \mathrm{rpm}$. After incubation period, serial dilutions were performed up to $1 \times 10^{6}$ of which $100 \mu \mathrm{L}$ were taken and boxes were planted with MHB medium. The plates were incubated at $28^{\circ} \mathrm{C}$ for $72 \mathrm{~h}$ and growth colonies were counted, expressed as $\mathrm{CFU} / \mathrm{mL}$. Controls were supplemented with MSN $(5 \mathrm{mg} / \mathrm{mL})$ and AMPs $(0.5 \mathrm{mg} / \mathrm{mL})$ in PBS [33]. The experiments were carried out by duplicate.

\subsection{MSN against Enzymatic Degradation of AMPS}

After removing the supernatant and drying the MSN/AMP complexes, $200 \mu \mathrm{L}$ of the pepsin $(1 \mathrm{mg} / \mathrm{mL})$ were added and incubated at $37^{\circ} \mathrm{C}$ for $16 \mathrm{~h}$ under constant shaking. The microtubes were then centrifuged at $5000 \times g$ for $10 \mathrm{~min}$ at $4{ }^{\circ} \mathrm{C}$. The resulting pellet was washed twice with deionized water and centrifuged at $5000 \times g$ for $10 \mathrm{~min}$ at $4{ }^{\circ} \mathrm{C}$ between each wash. MSN/AMPs complexes were resuspended in $3 \mathrm{~mL}$ of diluted Cmm culture and incubated at $28^{\circ} \mathrm{C}$ for $24 \mathrm{~h}$ at $180 \mathrm{rpm}$. After the incubation period, serial dilutions were performed up to $1 \times 10^{6}$ of which $100 \mu \mathrm{L}$ were taken and Petri dishes were poured with $30 \mathrm{~mL}$ MHB medium. The plates were incubated at $28{ }^{\circ} \mathrm{C}$ for $72 \mathrm{~h}$ and the colonies were counted, bacterial growth was expressed as CFU $/ \mathrm{mL}$. Controls were prepared with MSN $(5 \mathrm{mg} / \mathrm{mL})$ in PBS and AMPs $(1 \mathrm{mg} / \mathrm{mL})$ treated with protease $(1 \mathrm{mg} / \mathrm{mL})$ in a 5:1 ratio (peptide:enzyme) [33]. The experiments for this assay were performed by duplicate.

\subsection{Statistical Analysis}

Data of measurements of the growth inhibition halos and the CFU/mL were presented as the mean and the bars represent the standard deviation. Data analysis was performed 
using one-way analysis of variance (ANOVA). The Tukey's test was used to calculate $p$-values, $p$-values of $\leq 0.0028$ were considered statistically significant.

\section{Results}

\subsection{Construction, Expression and Purification of Recombinant Proteins}

Two gene constructs were designed, encoding the defensin $\mathrm{h} \beta \mathrm{D} 2$ and the mutant $(\mathrm{h} \beta \mathrm{D} 2-\mathrm{M})$, the open reading frame (ORF) encoding these peptides, cloned in the expression vectors are shown in Figure 1A. Orientation of DNA fragments encoding h $\beta D 2$ and h $\beta D 2-$ $\mathrm{M}$ into the pCri-4a vector was assessed by digestion with the restriction enzymes NcoI and XhoI, as well as DNA sequencing, confirming no DNA changes were present in the ORFs.

Recombinant proteins were present in both soluble and insoluble fraction. The TRX$\mathrm{h} \beta \mathrm{D} 2$ fusion protein had a molecular weight of $18 \mathrm{kDa}$ which coincides with the theoretical weight. After cleavage by TEV protease and analyzing the unbound fraction of a second purification step by $\mathrm{Ni}^{2+}-\mathrm{IMAC}$, a band near to $4.6 \mathrm{kDa}$ assigned to $\mathrm{h} \beta \mathrm{D} 2$ was observed. Similar results were obtained for TRX-h $\beta \mathrm{D} 2-\mathrm{M}$ and $\mathrm{h} \beta \mathrm{D} 2-\mathrm{M}$, the complete purification processes for both peptides are summarized in Figure $1 B, C$. The yields of the $h \beta D 2, h \beta D 2$ $\mathrm{M}$ and TRX-h $\beta \mathrm{D} 2-\mathrm{M}$ proteins were $1.23,1.38$ and $11.96 \mathrm{mg}$ per liter of culture respectively, with more than $90 \%$ purity according to a densitometry analysis.

\subsection{Antimicrobial Activity Assays against Cmm}

The antimicrobial activity of AMPs under both basic and acidic $\mathrm{pH}$ conditions against $\mathrm{Cmm}$ was evaluated. $\mathrm{CH}_{3} \mathrm{COOH}$ pH 2.4 and Tris $50 \mathrm{mM} \mathrm{pH} 8.4$ did not show antimicrobial activity against the strain under study, this same behavior was observed for TRX-h $\beta \mathrm{D} 2$ under both $\mathrm{pH}$ conditions. On the other hand, $\mathrm{h} \beta \mathrm{D} 2$, TRX-h $\beta \mathrm{D} 2-\mathrm{M}$ and $\mathrm{h} \beta \mathrm{D} 2-\mathrm{M}$ exhibited inhibition halos at the evaluated $\mathrm{pH}$ (Figure 2); for the three AMPs, the zones of inhibition increased as the sample volume increased.

The AMPs that inhibited the growth of $\mathrm{Cmm}$ on the plaque diffusion method, $\mathrm{h} \beta \mathrm{D} 2$, TRX-h $\beta$ D2-M and $\mathrm{h} \beta \mathrm{D} 2-\mathrm{M}$ exhibited strong antimicrobial activity against $\mathrm{Cmm}$ with $\mathrm{IC}_{50}$ values between 1.5 and $20 \mu \mathrm{g} / \mathrm{mL}$ (Table 1 ). The activity of $\mathrm{h} \beta \mathrm{D} 2-\mathrm{M}$ was higher than $\mathrm{h} \beta \mathrm{D} 2$ and TRX-h $\beta \mathrm{D} 2-\mathrm{M}$ under both acidic and basic $\mathrm{pH}$ conditions.

Table 1. $\mathrm{IC}_{50}$ of the recombinant AMPs.

\begin{tabular}{cc}
\hline Protein & IC $_{\mathbf{5 0}}(\mu \mathrm{g} / \mathrm{mL})$ \\
\hline $\mathrm{h} \beta \mathrm{D} 2$ in Tris & $3.61 \pm 0.47$ \\
$\mathrm{~h} \beta \mathrm{D} 2$ in $\mathrm{CH}_{3} \mathrm{COOH}$ & $3.64 \pm 0.33$ \\
$\mathrm{~h} \beta \mathrm{D} 2-\mathrm{M}$ in Tris & $1.75 \pm 0.13$ \\
$\mathrm{~h} \beta \mathrm{D} 2-\mathrm{M}$ in $\mathrm{CH}_{3} \mathrm{COOH}$ & $1.56 \pm 0.16$ \\
$\mathrm{TRX}-\mathrm{h} \beta \mathrm{D} 2-\mathrm{M}$ in Tris & $19.99 \pm 3.55$ \\
$\mathrm{TRX}-\mathrm{h} \beta \mathrm{D} 2-\mathrm{M}$ in $\mathrm{CH}_{3} \mathrm{COOH}$ & $6.17 \pm 0.08$ \\
\hline
\end{tabular}



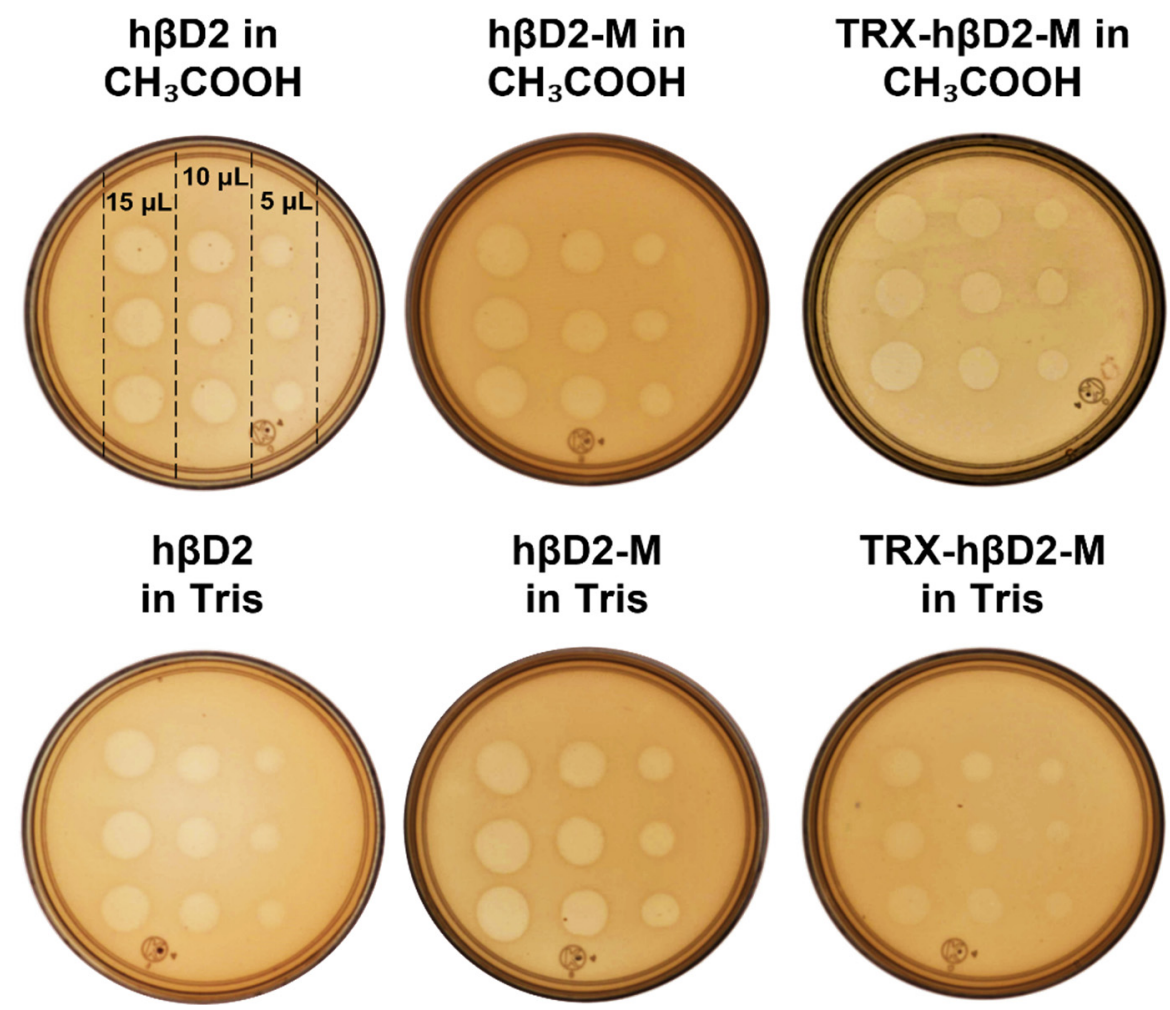

TRX-hßD2-M in Tris

Figure 2. Antimicrobial activity of AMPs by the plaque diffusion method. Different volumes of the sample of interest were deposited on each plate in triplicate at a concentration of $50 \mu \mathrm{M}$.

\subsection{MSN Characterization}

Based on the different treatments that were carried out (Table S1), the conditions with which it is possible to obtain MSN with sizes lower than $150 \mathrm{~nm}$ were found. According to DLS analysis, it was determined that the particles obtained had a wide size distribution with a mode of $220 \mathrm{~nm}$ when resuspended in PBS (right inset of Figure 3A), this result was corroborated by SEM analysis where particles of spherical morphology with sizes ranging from about 80-140 nm were observed (Figure 3A and left insert of Figure 3A). By TEM it was possible to appreciate aggregated spherical particles of sizes like those obtained by SEM with disordered mesopores of variable size (Figure 3B). In order to determine the functional groups involved in the adsorption of AMPs, the material was analyzed by FT-IR (Figure 3C). The spectrum obtained presented vibration bands centered at 3431, 1080, 960,800 and $468 \mathrm{~cm}^{-1}$ attributed to stretching vibrations of the O-H group of the water molecules linked to hydrogen (H-O-H-H), stretching vibrations of the Si-O covalent bond, stretching vibrations in the plane of the $\mathrm{Si}-\mathrm{O}$ bond of the silanol groups $(\mathrm{Si}-\mathrm{OH})$, vibrations symmetric tension of the Si-O-Si bonds and symmetric bending vibrations of the $\mathrm{Si}-\mathrm{O}-\mathrm{Si}$ bonds of the siloxane bonds, respectively [38,39]. Moreover, the Raman spectrum obtained exhibited peaks centered at 490 and $980 \mathrm{~cm}^{-1}$ associated with the vibration of oxygen in $\mathrm{Si}-\mathrm{O}-\mathrm{Si}$ and the vibration of the silanol group (Si-O-H), respectively (Figure $3 \mathrm{C})$. The relative amplitude of the last peak has been attributed to a high specific surface area [40]. It is important to mention that these results only refer to the material obtained by treatment 1 . 

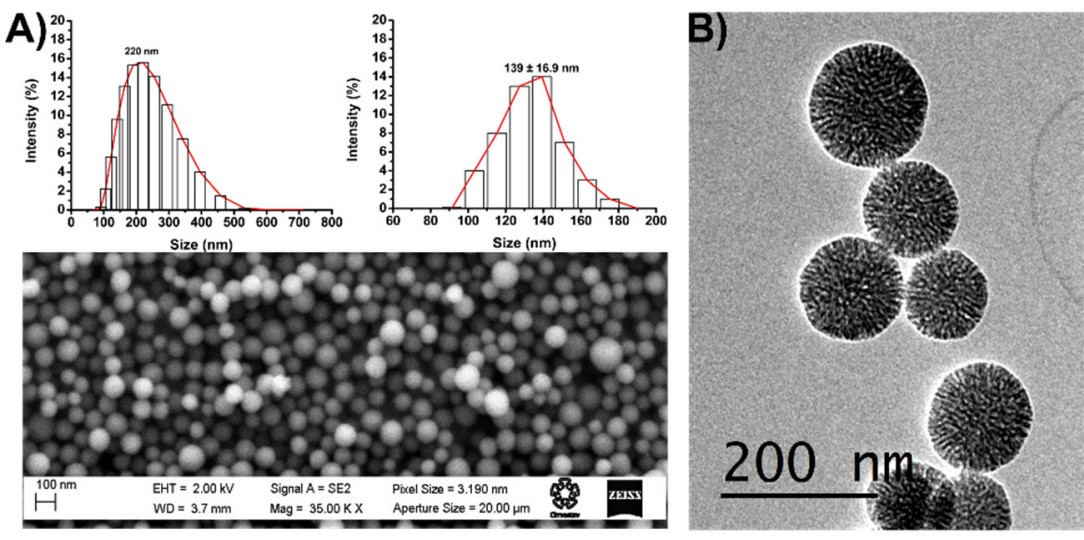

C) Wavenumber $\left(\mathrm{cm}^{-1}\right)$

40003600320028002400200016001200800400
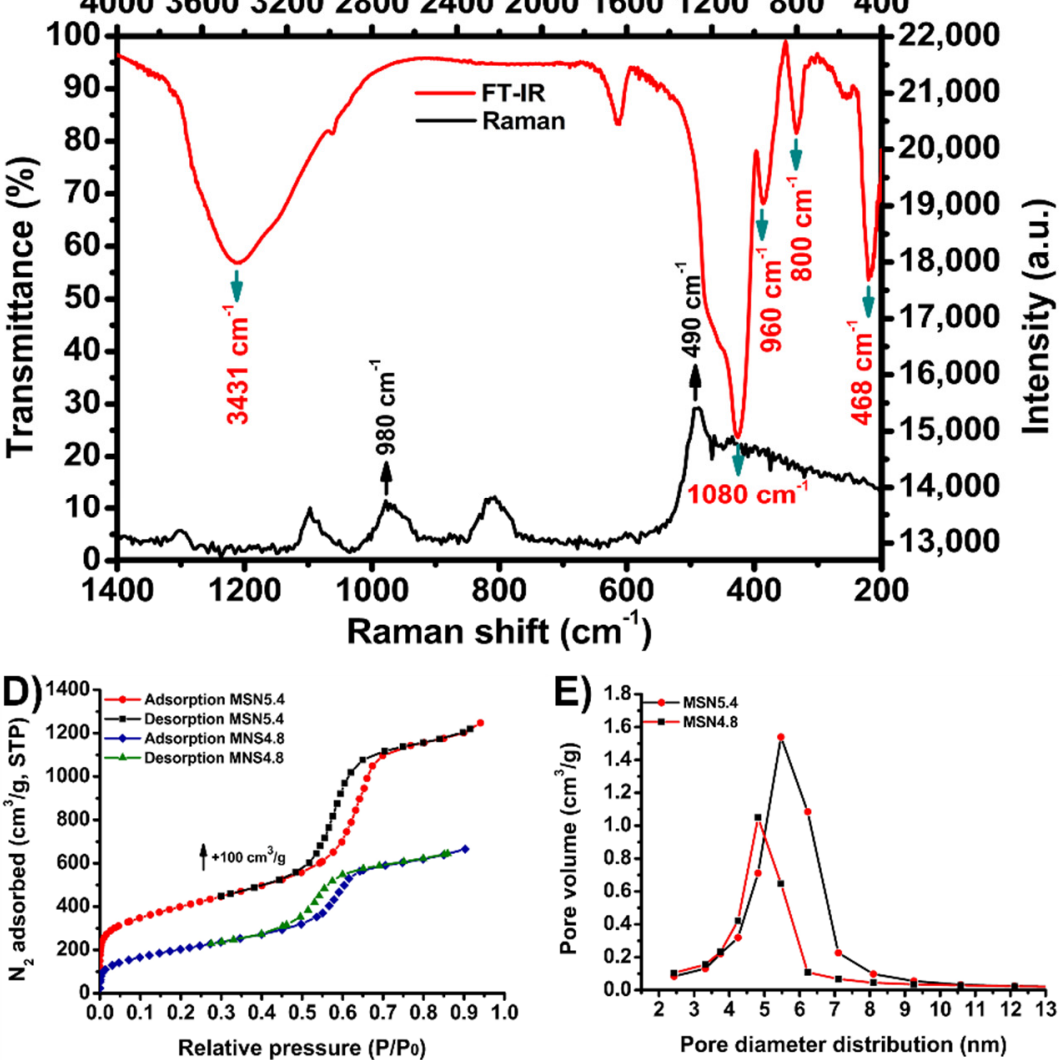

Figure 3. Characterization of MSN5.4. (A) SEM micrograph, (B) TEM micrograph, (C) FT-IR and Raman spectra, (D) nitrogen adsorption-desorption isotherms and (E) pore diameter distribution (BJH model).

The $\mathrm{N}_{2}$ adsorption-desorption results present isotherms type IV and hysteresis loops $\mathrm{H} 1$, where these patterns the presence of mesoporous analysis revealed the obtained material by treatment 1 (MSN5.4) had the best characteristics with mean pore size, pore volume (BJH model) and specific surface area (BET model) of $5.4 \mathrm{~nm}, 1.77 \mathrm{~cm}^{3} / \mathrm{g}$ and $1021.4 \mathrm{~m}^{2} / \mathrm{g}$, respectively (Figure 3D,E). The results of these analyses are summarized in Table 2. According to the results, the modifications made to the methodology proposed by $\mathrm{Gu}$ [35] had a significant effect on the pore size of the MSN since it increased from 4.6 to 4.8 and $5.4 \mathrm{~nm}$ for the MSN-4.8 and MSN-5.4, respectively. 
Table 2. Summary of the properties of the synthesized mesoporous silica matrices.

\begin{tabular}{cccc}
\hline Mesoporous Silicates & Pore Diameter $^{\mathbf{a}}(\mathbf{n m})$ & Poro Volume $^{\left(\mathbf{c m}^{\mathbf{3}} / \mathbf{g}\right)}$ & ${\text { BET Surface Area }\left(\mathbf{m}^{2} / \mathbf{g}\right)}$ \\
\hline MSN5.4 & 5.4 & 1.77 & 1021.4 \\
MSN4.8 & 4.8 & 1.02 & 711.4 \\
MSN0.9 & 0.9 & 0.31 & 653.2 \\
MSN0.9' & 0.9 & 0.30 & 688.5 \\
\hline
\end{tabular}

${ }^{\text {a }}$ Calculated using the BJH model from the desorption isotherms.

\subsection{Adsorption and Release of AMPs}

Based on the characterization results, MSN5.4 was chosen to carry out the adsorption and release tests of the AMPs under study. Regarding adsorption, 99.14, 99.08 and $99.46 \%$ of the evaluated concentration of $\mathrm{h} \beta \mathrm{D} 2$, TRX-h $\beta \mathrm{D} 2-\mathrm{M}$ and $\mathrm{h} \beta \mathrm{D} 2-\mathrm{M}$ were adsorbed on the MSN, respectively (Figure S1). This means that of the $500 \mathrm{mg}$ of AMPs that were added, more than $495 \mathrm{mg}$ were adsorbed in the MSN.

Desorption assays, performed with $\mathrm{h} \beta \mathrm{D} 2-\mathrm{M}$ and TRX-h $\beta \mathrm{D} 2-\mathrm{M}$ demonstrated the release of the proteins of $5 \mu \mathrm{g} / \mathrm{mL}$ at $24 \mathrm{~h}$. $\mathrm{h} \beta \mathrm{D} 2-\mathrm{M}$ and TRX-h $\beta \mathrm{D} 2-\mathrm{M}$ released a maximum of $41 \mu \mathrm{g} / \mathrm{mL}$ and $20 \mu \mathrm{g} / \mathrm{mL}$ at 96 and $168 \mathrm{~h}$, respectively. On the other hand, h $\beta \mathrm{D} 2$ desorption was registered after $120 \mathrm{~h}(2.8 \mu \mathrm{g} / \mathrm{mL})$; however, after that time its release rate was gradually increased, even exceeding TRX-h $\beta \mathrm{D} 2-\mathrm{M}$ (Figure $4 \mathrm{~A}$ ). As far as this experiment was monitored, it was determined that approximately 55, 81 and $229 \mu \mathrm{g}$ of $\mathrm{h} \beta \mathrm{D} 2$, TRX-h $\beta \mathrm{D} 2-\mathrm{M}$ and $\mathrm{h} \beta \mathrm{D} 2-\mathrm{M}$ were released from MSN5.4, respectively (Figure S2).

A)
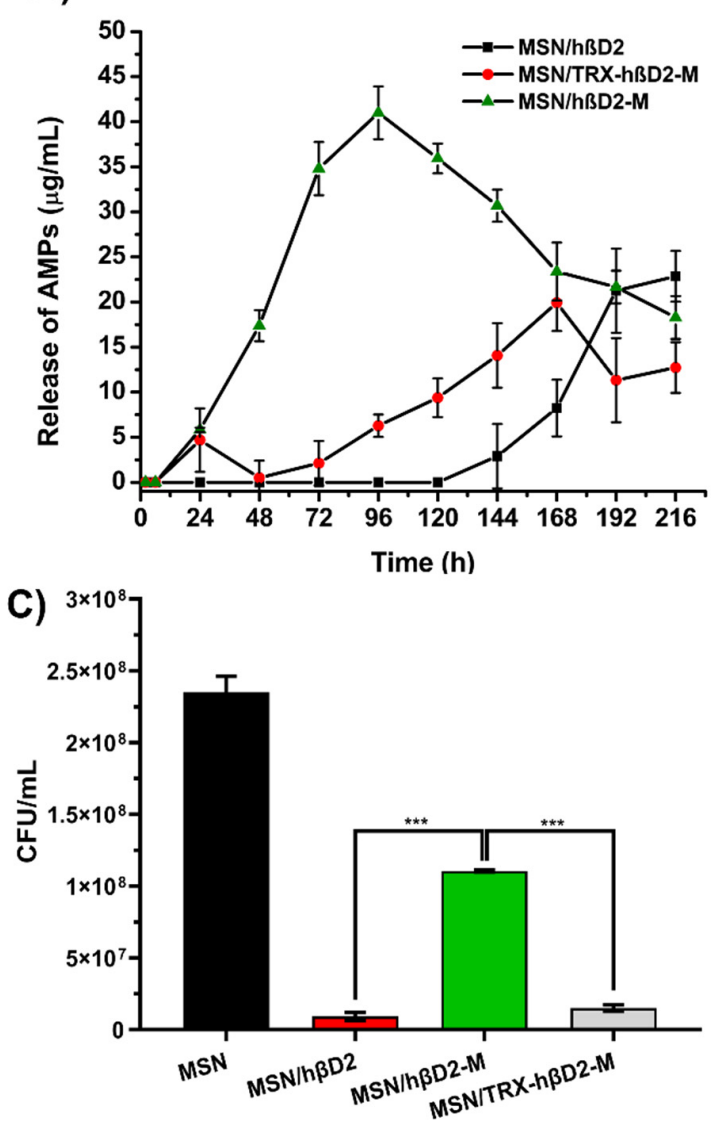
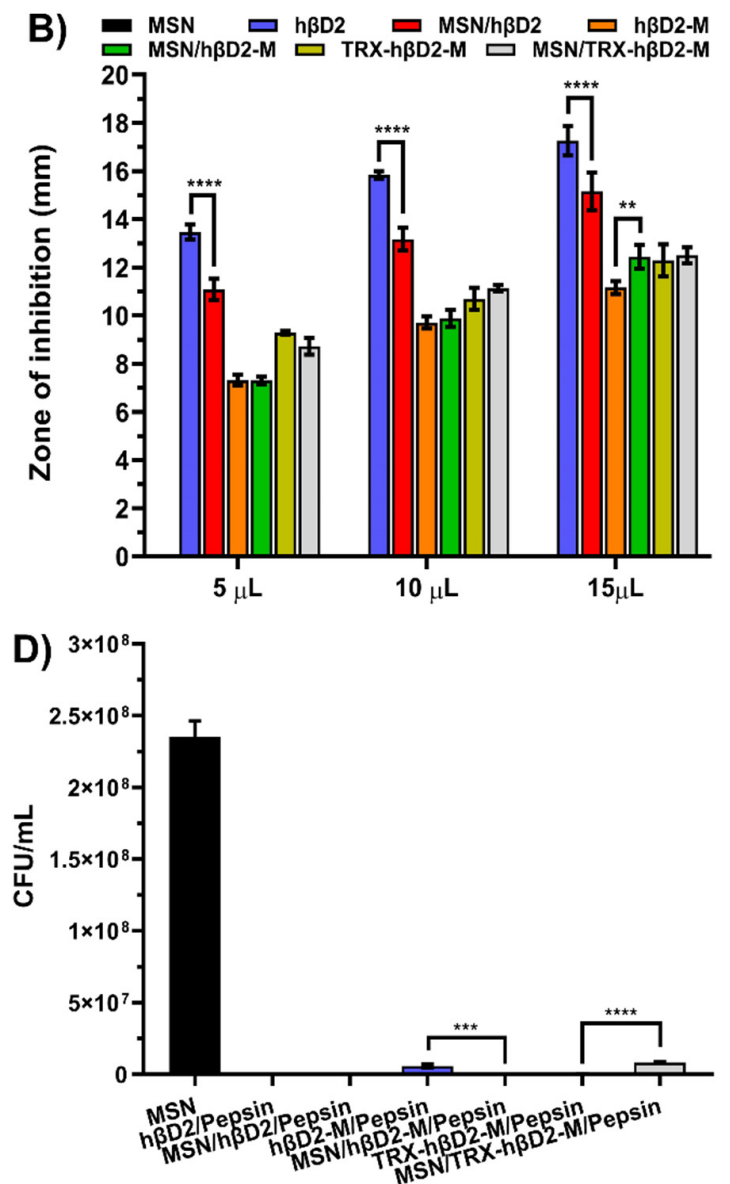

Figure 4. Characterization of the MSN/AMPs complexes. (A) Concentration of AMPs released from MSN5.4, (B) evaluation of antimicrobial activity by plaque diffusion $\left(^{* *}, p \leq 0.0028 ;{ }^{* * * *}, p<0.0001\right),($ C) evaluation of antimicrobial activity in liquid medium $\left(^{* * *}, p \leq 0.0001\right)$ and (D) effect of pepsin on MSN/AMPs complexes $(* * *, p \leq 0.0005 ; * * *, p<0.0001)$. 


\subsection{Bioactivity of MSN Loaded with AMPs against Cmm}

The bioactivity evaluation of the MSN5.4 loaded with the AMPs against Cmm was performed in both solid (qualitative) and liquid medium (quantitative). Figure 4B shows the bar graph corresponding to the measurements of the inhibition halos of MSN/AMPs. In general, the three AMPs adsorbed by MSN5.4 presented antimicrobial activity, which was proportional to the sample volume. In contrast, MSN/PBS control did not show cell growth inhibition. There was no statistically significant difference between TRX-h $\beta$ D2$\mathrm{M}$ and MSN/TRX-h $\beta \mathrm{D} 2-\mathrm{M}$ in the three evaluated sample volumes. On the other hand, free standing $h \beta D 2$ showed greater inhibition than MNS/h $\beta D 2$, likely due to a greater diffusivity of the peptide in the medium, since $\mathrm{h} \beta \mathrm{D} 2$ is slowly released from MSN. Opposite case, it was observed with $\mathrm{h} \beta \mathrm{D} 2-\mathrm{M}$ and the MNS/h $\beta \mathrm{D} 2-\mathrm{M}$ complex at $15 \mu \mathrm{L}$ given that $\mathrm{h} \beta \mathrm{D} 2-\mathrm{M}$ presented a greater inhibition halo than MSN/h $\beta \mathrm{D} 2-\mathrm{M}$.

On the other hand, the tests carried out in liquid medium showed $\mathrm{Cmm}$ growth inhibition by 96,47 and $94 \%$ when $\mathrm{h} \beta \mathrm{D} 2, \mathrm{~h} \beta \mathrm{D} 2-\mathrm{M}$ and TRX-h $\beta \mathrm{D} 2-\mathrm{M}$ were adsorbed on MSN5.4 (loaded with $0.5 \mathrm{mg}$ of AMPs), respectively (Figure 4C). In the same way as in the previous test, MSN/PBS (control) did not show bacterial inhibition against $\mathrm{Cmm}$. To note is that AMPs without MSN5.4 completely inhibited the growth of $\mathrm{Cmm}$.

\subsection{Effect of Peptidase on AMPs and the MSN/AMPs Complex}

To determine whether MSN protected AMPs from enzymatic degradation, a proteolytic degradation study was carried out using the peptidase pepsin. Considering the diversity of proteases in nature, further investigation will be required to evaluate other enzymes likely present in tomato crops. The results of this preliminary study indicate that AMPs without the mesoporous matrix are not susceptible to the catalytic activity of pepsin since $\mathrm{h} \beta \mathrm{D} 2$, TRX-h $\beta \mathrm{D} 2-\mathrm{M}$ and $\mathrm{h} \beta \mathrm{D} 2-\mathrm{M}$ inhibited the growth of $\mathrm{Cmm}$ by $99.98,99.92$ and $97.57 \%$, respectively (Figure $4 \mathrm{D}$ ). However, the MSN/h $\beta \mathrm{D} 2$ and MSN/h $\beta \mathrm{D} 2-\mathrm{M}$ complexes treated with the protease showed higher antimicrobial activity since they inhibited the growth of $\mathrm{Cmm}$ by 100 and $99.9 \%$, respectively. On the other hand, TRX-h $\beta \mathrm{D} 2-\mathrm{M}$ treated with pepsin presented a higher antimicrobial activity than the MSN/TRX-h $\beta$ D2-M complex (inhibited the growth of $\mathrm{Cmm}$ by $96.53 \%$ ).

\section{Discussion}

It has been shown that $\mathrm{h} \beta \mathrm{D} 2$, as well as other AMPs, can inhibit the growth of multidrug resistant strains [22,34]. In the present work, the recombinant production of $h \beta D 2$, TRX-h $\beta D 2-M$ and $h \beta D 2-M$ was carried out to evaluate their activity. When analyzing the unbound fraction of the last purification step for $h \beta D 2$ and $h \beta D 2-M$ by Tricine-SDS-PAGE, bands with a weight of $4.5 \mathrm{kDa}$ corresponding with theoretical weight of defensins (Table S2). However, a band of $9 \mathrm{kDa}$ was also observed for both cases. Previous studies have reported that $\mathrm{h} \beta \mathrm{D} 2$ coexists as a mixture of aggregated peptides that are mostly dimers and their multimerization state depends on their concentration (the higher the concentration the bigger amount of formed homo-oligomers), so the $9 \mathrm{kDa}$ band can be attributed to the $\mathrm{h} \beta \mathrm{D} 2$ dimer [22,41]. The $\mathrm{h} \beta \mathrm{D} 2$ dimer is formed by the interaction of the $\beta 1$ chains of both monomers, resulting in the formation of a six-chain $\beta$ sheet, however, this interaction is limited by two hydrogen bridges between His16 and the skeleton of Cys15. However, it also involves the hydroxyl groups of Tyr24, this dimer is mainly stabilized by van de Waals forces, with residues Pro5, Ala13, Ile14, Cys15, His16 and Pro17 responsible for most of these interactions [41].

$\mathrm{h} \beta \mathrm{D} 2$, TRX-h $\beta \mathrm{D} 2-\mathrm{M}$ and $\mathrm{h} \beta \mathrm{D} 2-\mathrm{M}$ showed antimicrobial activity on $\mathrm{Cmm}$ both in solid and liquid medium. Based on the bibliographic review that was carried out, the $\mathrm{IC}_{50}$ value presented by $\mathrm{h} \beta \mathrm{D} 2$ and $\mathrm{h} \beta \mathrm{D} 2 \mathrm{-M}$ (acid buffer) is lower than that reported for inhibiting Cmm using AMPs [42-44].

It should be mentioned that the $\mathrm{h} \beta \mathrm{D} 2-\mathrm{M}$ mutant presented a lower $\mathrm{IC}_{50}$ than $\mathrm{h} \beta \mathrm{D} 2$, the reason why $\mathrm{h} \beta \mathrm{D} 2-\mathrm{M}$ exhibits better antimicrobial activity against $\mathrm{Cmm}$ compared to $\mathrm{h} \beta \mathrm{D} 2$ could be attributed to our replacement of Pro45 by an Arg at the carboxyl terminal end. By 
changing the content of Arg in the sequence of an AMP, a higher net positive charge was obtained due to a guanidinium functional group present in the replaced amino acid. Thus a promoting of long-range electrostatic attraction towards negatively charged bacterial membranes is done $[45,46]$. The mutation carried out served its purpose by improving the antimicrobial activity of $\mathrm{h} \beta \mathrm{D} 2$ on $\mathrm{Cmm}$. Likewise, it is important to emphasize that $\mathrm{h} \beta \mathrm{D} 2-\mathrm{M}$ presents antimicrobial activity even when it is fused to $\operatorname{Tr} x \mathrm{~A}$ (TRX-h $\beta \mathrm{D} 2-\mathrm{M})$, until now there are few reports indicating that an AMP presents activity linked to a fusion protein $[47,48]$.

MSN5.4 and MSN4.8 presented a type IV adsorption-desorption isotherm of $\mathrm{N}_{2}$ with an imminent type of $\mathrm{HI}$ hysteresis loop which are characteristic of mesopores in the form of independent thin cylindrical channels with a wide size distribution [28,49]. On the other hand, the increase in the amount of DMHA accompanied by the decrease in TEOS in the synthesis of MSN0.9 and MSN0.9' led to a considerable decrease in pore diameter, pore volume and surface area, therefore both materials presented a characteristic behavior of microporous materials like a type I isotherm $(<2 \mathrm{~nm})$; this could be attributed to the fact that the TEOS in less quantity entered directly into the hydrophobic area of the CTAB micelles, preventing the DMHA from fulfilling its role as a mediator of the pore size, in addition, the excess DMHA is not transferred to the CTAB micelles if not to those of F127 resulting in obtaining microporous materials $[35,50]$.

Using different complementary techniques, we determined that the pore size and diameter for MSN5.4 were 140 and $5.4 \mathrm{~nm}$, respectively. On the other hand, according to the Pymol software, the dimensions of the AMPs are less than the pore diameter of the MSN5.4 (Figure S3 and Table S2), so that AMPs can easily enter in the pores of the MSN5.4. The adsorption of $h \beta D 2, T R X-h \beta D 2$ and $h \beta D 2-M$ by MSN 5.4 was 99.14, 99.08 and $99.46 \%$. When analyzing MSN5.4 by FT-IR and Raman, silanol (hydrophilic) and siloxane (slightly hydrophobic) groups were identified. The adsorption process of biomolecules by mesoporous matrices such as MSN 5.4 is mainly governed by hydrophilic and hydrophobic interactions of the groups. silanol and siloxane and the regions with the same nature of the biomolecules, however, as the silanol groups are more exposed, it would be expected that the hydrophilic interactions predominate [29,39]. Despite having the atomic structure of $h \beta D 2$, it is difficult to ensure that residues carry out the interaction with the internal surface of MSN5.4.

By evaluating the desorption of AMPs by MSN5.4 in PBS by quantifying total protein for $216 \mathrm{~h}$, we determined that $\mathrm{h} \beta \mathrm{D} 2-\mathrm{M}$ and TRX-h $\beta \mathrm{D} 2-\mathrm{M}$ are released until after 24 and 48 $h$, respectively. TRX-h $\beta D 2-M$ presented desorption at $24 \mathrm{~h}$, however, the amount of protein decreased at $48 \mathrm{~h}$, this may be due to protein physiosorbed on the surface and not in the pores of the MSN and therefore it was easily released during the first $24 \mathrm{~h}$ [35]. $h \beta \mathrm{D} 2$ began to be resorbed until after $120 \mathrm{~h}$. The release of MSN AMPs at neutral $\mathrm{pH}$ is carried out by a diffusion process through the pores that is controlled by electrostatic interactions $[29,51]$.

The MSN/h $\beta \mathrm{D} 2$ and MSN/TRX-h $\beta \mathrm{D} 2$ complexes in liquid medium greatly inhibited the growth of $\mathrm{Cmm}$. However, with no statistically significant difference between them within the conditions of our experiment. On the other hand, the MSN/h $\beta \mathrm{D} 2$ complex only inhibited the growth of $\mathrm{Cmm}$ by $53 \%$, this result is nor consistent with what was obtained in the desorption tests neither the evaluation of antimicrobial activity in solid medium. With respect to the desorption test, $\mathrm{h} \beta \mathrm{D} 2$ was released faster than the MSN compared to the other AMPs. On the solid medium the MSN $/ \mathrm{h} \beta \mathrm{D} 2$ complex presented inhibition halos of greater diameter than $\mathrm{h} \beta \mathrm{D} 2$ without the matrix $(15 \mu \mathrm{L})$. The above suggests that the material in the liquid MHB presented some alterations on its surface such as the blocking of its pores by some compound in the medium as a consequence the complex had a lower antimicrobial activity [33,52]. As mentioned above, the AMPs without the mesoporous matrix completely inhibited the growth of $\mathrm{Cmm}$, this is because the $\mathrm{IC}_{50}$ concentration was exceeded. It is possible that $\mathrm{h} \beta \mathrm{D} 2-\mathrm{M}$ modifies its charge (more cationic) but since it does not have the matrix present and the most anionic is the wall of the bacteria, its activity is not affected antimicrobial. 
The adsorption and posterior release of multiple AMPs has been carried out in different mesoporous matrices $[29,32,38]$, in general it has been determined that the matrix confers protection to AMPs from multiple factors and enhances their antimicrobial activity when they are release, a clear example is that reported by Durak et al. [33] who adsorbed bactofencin A within two different mesoporous matrices and when facing these complexes (MSN/AMPs) to the activity of several proteases, they observed that bactofencin A, had a better activity antimicrobial against Staphylococcus aureus compared to the peptide without the mesoporous matrix. It is very important to mention that our AMPs were not so susceptible to pepsin degradation. Since they still significantly inhibited the growth of $\mathrm{Cmm}$, after exposition to pepsin. However, when they were adsorbed on MSN5.4, their antimicrobial activity was significantly higher. On the other hand, the MSN/TRX-h $\beta$ D2-M complex presented a lower antimicrobial activity in contrast to the peptide without the matrix, here it is possible that the pepsin has carried out some type of interaction with the material causing the clogging of the pores and being TRX-h $\beta \mathrm{D} 2-\mathrm{M}$ the largest protein had a lower degree of release and therefore the complex presented a lower antimicrobial activity against $\mathrm{Cmm}$ [52]. According to the above, AMPs with and without MSN could be applied in a liquid medium to disinfect seeds and young seedlings, as well as to combat $\mathrm{Cmm}$ when it is infecting S. lycopersicum plants in advanced stages of development and in this way its spread could be reduced.

\section{Conclusions}

In this work, we demonstrated that recombinant expressed AMPs $h \beta D 2$, TRX-h $\beta$ D2$\mathrm{M}$ and $\mathrm{h} \beta \mathrm{D} 2-\mathrm{M}$ in E. coli inhibit the growth of $\mathrm{Cmm}$ in both solid and liquid tests. The MSN/AMPs complexes (h $\beta \mathrm{D} 2$ and TRX-h $\beta \mathrm{D} 2-\mathrm{M})$ in solution after being treated with a pepsin were shown to have better antimicrobial activity against $\mathrm{Cmm}$ compared to AMPs without the mesoporous matrix. Thus, AMPs and complex MSN/AMPs are excellent candidates for the potential management of bacterial tomato canker, as well as other diseases caused by the genus Clavibacter.

Supplementary Materials: The following are available online at https://www.mdpi.com/article/ $10.3390 /$ nano11082144/s1, Figure S1. \% AMPs loaded onto MSN5.4 after $16 \mathrm{~h}$ incubation to $4{ }^{\circ} \mathrm{C}$. Figure S2. Cumulative release of AMPs with respect to time. Figure S3. AMPS measurements with the Pymol software. Table S1. Different treatments performed for the synthesis of MSN. Table S2. Physicochemical characteristics of AMPs.

Author Contributions: Conceptualization, Methodology, Validation, Data curation, Formal analysis, Investigation, Writing—original draft preparation: G.M.-P. Writing—review and editing: S.G.-H., R.R.-M. and B.X.-C. Visualization and Supervision: S.G.-H., R.R.-M. and B.X.-C. Funding acquisition: S.G.-H. and B.X.-C. All authors have read and agreed to the published version of the manuscript.

Funding: This work was supported by the National Council for Science and Technology Research (CONACyT) grant no. 2012-2-01234 (to B.X.-C.) and CINVESTAV.

Institutional Review Board Statement: Not applicable.

Informed Consent Statement: Not applicable.

Data Availability Statement: Data is contained within the article or Supplementary Material.

Acknowledgments: We thank J.A.G.-C. from CINVESTAV for performing SEM and TEM. G.M.-P. acknowledges doctoral fellowship support from CONACyT fellow (332010).

Conflicts of Interest: The authors declare no conflict of interest.

\section{References}

1. Food and Agriculture Organization. FAOSTAT. Available online: http://www.fao.org/faostat/en/\#data/QC/visualize (accessed on 3 March 2021).

2. Dey, R.; Raghuwanshi, R. Comprehensive assessment of growth parameters for screening endophytic bacterial strains in Solanum lycopersicum (tomato). Heliyon 2020, 6, e05325. [CrossRef] 
3. Parrotta, L.; Aloisi, I.; Faleri, C.; Romi, M.; Del Duca, S.; Cai, G. Chronic heat stress affects the photosynthetic apparatus of Solanum lycopersicum L. cv Micro-Tom. Plant Physiol. Biochem. 2020, 154, 463-475. [CrossRef]

4. Chalupowicz, L.; Barash, I.; Reuven, M.; Dror, O.; Sharabani, G.; Gartemann, K.H.; Eichenlaub, R.; Sessa, G.; Manulis-Sasson, S. Differential contribution of Clavibacter michiganensis ssp. michiganensis virulence factors to systemic and local infection in tomato. Mol. Plant Pathol. 2017, 18, 336-346. [CrossRef]

5. Ramachandran, S.; Dobhal, S.; Alvarez, A.M.; Arif, M. Improved multiplex TaqMan qPCR assay with universal internal control offers reliable and accurate detection of Clavibacter michiganensis. J. Appl. Microbiol. 2021, 1-12. [CrossRef]

6. Sai-Anand, G.; Sivanesan, A.; Benzigar, M.R.; Singh, G.; Gopalan, A.I.; Baskar, A.V.; Ilbeygi, H.; Ramadass, K.; Kambala, V.; Vinu, A. Recent progress on the sensing of pathogenic bacteria using advanced nanostructures. Bull. Chem. Soc. Jpn. 2019, 92, 216-244. [CrossRef]

7. Nandi, M.; Macdonald, J.; Liu, P.; Weselowski, B.; Yuan, Z.C. Clavibacter michiganensis ssp. michiganensis: Bacterial canker of tomato, molecular interactions and disease management. Mol. Plant Pathol. 2018, 19, 2036-2050. [CrossRef]

8. Gartemann, K.H.; Kirchner, O.; Engemann, J.; Gräfen, I.; Eichenlaub, R.; Burger, A. Clavibacter michiganensis subsp. michiganensis: First steps in the understanding of virulence of a Gram-positive phytopathogenic bacterium. J. Biotechnol. 2003, 106, 179-191. [CrossRef] [PubMed]

9. Romero, A.M.; Vega, D.; Pizzorno, R.; Cordon, G.; Correa, O.S. Hydraulic and leaf reflectance alterations induced by Clavibacter michiganensis subsp. michiganensis on tomato plants. Eur. J. Plant Pathol. 2018, 152, 567-572. [CrossRef]

10. Vega, D.; Romero, A.M. Survival of Clavibacter michiganensis subsp. michiganensis in tomato debris under greenhouse conditions. Plant Pathol. 2016, 65, 545-550. [CrossRef]

11. Ombiro, G.S.; Sawai, T.; Noutoshi, Y.; Nishina, Y.; Matsui, H.; Yamamoto, M.; Toyoda, K.; Ichinose, Y. Specific growth inhibitors of Ralstonia solanacearum, Xanthomonas oryzae pv. oryzae, X. campestris pv. campestris, and Clavibacter michiganensis subsp. michiganensis. Microbiol. Res. 2018, 215, 29-35. [CrossRef]

12. Lahiri, S.; Orr, D. Biological Control in Tomato Production Systems: Theory and Practice; Elsevier Inc.: Amsterdam, The Netherlands, 2018; ISBN 9780128135082.

13. Wittmann, J.; Brancato, C.; Berendzen, K.W.; Dreiseikelmann, B. Development of a tomato plant resistant to Clavibacter michiganensis using the endolysin gene of bacteriophage CMP1 as a transgene. Plant Pathol. 2016, 65, 496-502. [CrossRef]

14. Choi, J.; Baek, K.H.; Moon, E. Antimicrobial effects of a hexapetide KCM21 against Pseudomonas syringae pv. tomato DC3000 and Clavibacter michiganensis subsp. michiganensis. Plant Pathol. J. 2014, 30, 245-253. [CrossRef] [PubMed]

15. Sánchez-López, E.; Gomes, D.; Esteruelas, G.; Bonilla, L.; Lopez-Machado, A.L.; Galindo, R.; Cano, A.; Espina, M.; Ettcheto, M.; Camins, A.; et al. Metal-based nanoparticles as antimicrobial agents: An overview. Nanomaterials 2020, 10, 292. [CrossRef] [PubMed]

16. Singh, S.; Singh, P.; Kashyap, P.; Singh, M.; Azmal, S. Microbial pathogenesis promising role of defensins peptides as therapeutics to combat against viral infection. Microb. Pathog. 2021, 155, 104930. [CrossRef]

17. Li, K.; Li, W.; Chen, X.; Luo, T.; Mu, Y.; Chen, X. Molecular and functional identification of a $\beta$-defensin homolog in large yellow croaker (Larimichthys crocea). J. Fish Dis. 2021, 44, 391-400. [CrossRef] [PubMed]

18. Bahar, A.A.; Ren, D. Antimicrobial peptides. Pharmaceuticals 2013, 6, 1543-1575. [CrossRef]

19. Pazgier, M.; Hoover, D.M.; Yang, D.; Lu, W.; Lubkowski, J. Human $\beta$-defensins. Cell. Mol. Life Sci. CMLS 2006, 63, 1294-1313. [CrossRef]

20. Semple, F.; Dorin, J.R. $\beta$-Defensins: Multifunctional modulators of infection, inflammation and more? J. Innate Immun. 2012, 4, 337-348. [CrossRef]

21. Izadpanah, A.; Gallo, R.L. Antimicrobial peptides. J. Am. Acad. Dermatol. 2005, 52, 381-390. [CrossRef]

22. Järvå, M.; Phan, T.K.; Lay, F.T.; Caria, S.; Kvansakul, M.; Hulett, M.D. Human-defensin 2 kills Candida albicans through phosphatidylinositol 4,5-bisphosphate-mediated membrane permeabilization. Sci. Adv. 2018, 4, 1-10. [CrossRef]

23. Seyfi, R.; Kahaki, F.A.; Ebrahimi, T.; Montazersaheb, S.; Eyvazi, S.; Babaeipour, V.; Tarhriz, V. Antimicrobial Peptides (AMPs): Roles, Functions and Mechanism of Action. Int. J. Pept. Res. Ther. 2020, 26, 1451-1463. [CrossRef]

24. Zhuang, C.; Huo, H.; Yang, N.; Fu, Q.; Xue, T.; Zhu, Q.; Wang, B.; Liu, X.; Li, C. Characterization of antibacterial activities and the related mechanisms of a $\beta$-defensin in turbot (Scophthalmus maximus). Aquaculture 2021, 541, 736839. [CrossRef]

25. Gordon, Y.J.; Romanowski, E.G.; McDermott, A.M. Mini review: A review of antimicrobial peptides and their therapeutic potential as anti-infective drugs. Curr. Eye Res. 2005, 30, 505-515. [CrossRef] [PubMed]

26. Biswaro, L.S.; da Costa Sousa, M.G.; Rezende, T.M.B.; Dias, S.C.; Franco, O.L. Antimicrobial peptides and nanotechnology, recent advances and challenges. Front. Microbiol. 2018, 9, 1-14. [CrossRef] [PubMed]

27. Walia, N.; Dasgupta, N.; Ranjan, S.; Ramalingam, C.; Gandhi, M. Methods for nanoemulsion and nanoencapsulation of food bioactives. Environ. Chem. Lett. 2019, 17, 1471-1483. [CrossRef]

28. Luo, Z.; Deng, Y.; Zhang, R.; Wang, M.; Bai, Y.; Zhao, Q.; Lyu, Y.; Wei, J.; Wei, S. Peptide-laden mesoporous silica nanoparticles with promoted bioactivity and osteo-differentiation ability for bone tissue engineering. Colloids Surf. B Biointerfaces 2015, 131, 73-82. [CrossRef] [PubMed]

29. Flynn, J.; Mallen, S.; Durack, E.; O'Connor, P.M.; Hudson, S.P. Mesoporous matrices for the delivery of the broad spectrum bacteriocin, nisin A. J. Colloid Interface Sci. 2019, 537, 396-406. [CrossRef] 
30. Selvarajan, V.; Obuobi, S.; Lai, P.; Ee, R. Silica nanoparticles-A versatile tool for the treatment of bacterial infections. Front. Chem. 2020, 8, 1-16. [CrossRef]

31. Tenland, E.; Pochert, A.; Krishnan, N.; Rao, K.U.; Kalsum, S.; Braun, K.; Glegola-madejska, I.; Id, M.L. Effective delivery of the anti-mycobacterial peptide NZX in mesoporous silica nanoparticles. PLoS ONE 2019, 14, 1-16. [CrossRef]

32. Diosa, J.; Guzman, F.; Bernal, C.; Mesa, M. Formation mechanisms of chitosan-silica hybrid materials and its performance as solid support for KR-12 peptide adsorption: Impact on KR-12 antimicrobial activity and proteolytic stability. Integr. Med. Res. 2019, 9 , 890-901. [CrossRef]

33. Durack, E.; Mallen, S.; O'Connor, P.M.; Rea, M.C.; Ross, R.P.; Hill, C.; Hudson, S. Protecting bactofencin A to enable its antimicrobial activity using mesoporous matrices. Int. J. Pharm. 2019, 558, 9-17. [CrossRef]

34. Routsias, J.G.; Karagounis, P.; Parvulesku, G.; Legakis, N.J.; Tsakris, A. In Vitro bactericidal activity of human $\beta$-defensin 2 against nosocomial strains. Peptides 2010, 31, 1654-1660. [CrossRef]

35. Gu, J.; Huang, K.; Zhu, X.; Li, Y.; Wei, J.; Zhao, W.; Liu, C.; Shi, J. Sub-150nm mesoporous silica nanoparticles with tunable pore sizes and well-ordered mesostructure for protein encapsulation. J. Colloid Interface Sci. 2013, 407, 236-242. [CrossRef]

36. Liu, Z.; Ma, P.; Holtsmark, I.; Skaugen, M.; Eijsink, V.G.H.; Brurberg, M.B. New type of antimicrobial protein produced by the plant pathogen Clavibacter michiganensis subsp. michiganensis. Appl. Environ. Microbiol. 2013, 79, 5721-5727. [CrossRef]

37. Tay, D.K.S.; Rajagopalan, G.; Li, X.; Chen, Y.; Lua, L.H.L.; Leong, S.S.J. A new bioproduction route for a novel antimicrobial peptide. Biotechnol. Bioeng. 2011, 108, 572-581. [CrossRef] [PubMed]

38. Oliveira, L.F.A.D.M.; Silva, L.V.D.A.T.D.; Nascimento, T.G.D.; Almeida, L.; Calumby, R.J.N.; Nunes, Á.M.; Oliveira, L.M.T.D.M.; Fonseca, E.J.D.S. Antioxidant and antimicrobial activity of red propolis embedded mesoporous silica nanoparticles. Drug Dev. Ind. Pharm. 2020, 46, 1199-1208. [CrossRef] [PubMed]

39. Sahare, P.; Ayala, M.; Vazquez-Duhalt, R.; Pal, U.; Loni, A.; Canham, L.T.; Osorio, I.; Agarwal, V. Enhancement of peroxidase stability against oxidative self-inactivation by co-immobilization with a redox-active protein in mesoporous silicon and silica microparticles. Nanoscale Res. Lett. 2016, 11. [CrossRef]

40. Alessi, A.; Agnello, S.; Buscarino, G.; Gelardi, F.M. Structural properties of core and surface of silica nanoparticles investigated by Raman spectroscopy. J. Raman Spectrosc. 2013, 44, 810-816. [CrossRef]

41. Hoover, D.M.; Rajashankar, K.R.; Blumenthal, R.; Puri, A.; Oppenheim, J.J.; Chertov, O.; Lubkowski, J. The structure of human $\beta$-defensin-2 shows evidence of higher order oligomerization. J. Biol. Chem. 2000, 275, 32911-32918. [CrossRef] [PubMed]

42. Laird, M.; Piccoli, D.; Weselowski, B.; McDowell, T.; Renaud, J.; MacDonald, J.; Yuan, Z.C. Surfactin-producing bacillus velezensis 1B-23 and bacillus sp. 1D-12 protect tomato against bacterial canker caused by Clavibacter michiganensis subsp. michiganensis. J. Plant Pathol. 2020, 102, 451-458. [CrossRef]

43. Khazigaleeva, R.A.; Vinogradova, S.V.; Petrova, V.L.; Fesenko, I.A.; Arapidi, G.P.; Kamionskaya, A.M.; Govorun, V.M.; Ivanov, V.T. Antimicrobial activity of endogenous peptides of the moss Physcomitrella patens. Russ. J. Bioorganic Chem. 2017, 43, 248-254. [CrossRef]

44. Yokoyama, S.; Kato, K.; Koba, A.; Minami, Y.; Watanabe, K.; Yagi, F. Purification, characterization, and sequencing of antimicrobial peptides, Cy-AMP1, Cy-AMP2, and Cy-AMP3, from the cycad (Cycas revoluta) seeds. Peptides 2008, 29, 2110-2117. [CrossRef]

45. Cutrona, K.J.; Kaufman, B.A.; Figueroa, D.M.; Elmore, D.E. Role of arginine and lysine in the antimicrobial mechanism of histone-derived antimicrobial peptides. FEBS Lett. 2015, 589, 3915-3920. [CrossRef] [PubMed]

46. Andreev, K.; Bianchi, C.; Laursen, J.S.; Citterio, L.; Hein-Kristensen, L.; Gram, L.; Kuzmenko, I.; Olsen, C.A.; Gidalevitz, D. Guanidino groups greatly enhance the action of antimicrobial peptidomimetics against bacterial cytoplasmic membranes. Biochim. Biophys. Acta-Biomembr. 2014, 1838, 2492-2502. [CrossRef] [PubMed]

47. Lin, C.H.; Pan, Y.C.; Liu, F.W.; Chen, C.Y. Prokaryotic expression and action mechanism of antimicrobial LsGRP1C recombinant protein containing a fusion partner of small ubiquitin-like modifier. Appl. Microbiol. Biotechnol. 2017, 101, 8129-8138. [CrossRef] [PubMed]

48. Oh, R.; Lee, M.J.; Kim, Y.O.; Nam, B.H.; Kong, H.J.; Kim, J.W.; Park, J.Y.; Seo, J.K.; Kim, D.G. Myticusin-beta, antimicrobial peptide from the marine bivalve, Mytilus coruscus. Fish Shellfish. Immunol. 2020, 99, 342-352. [CrossRef] [PubMed]

49. Kachbouri, S.; Mnasri, N.; Elaloui, E.; Moussaoui, Y. Tuning particle morphology of mesoporous silica nanoparticles for adsorption of dyes from aqueous solution. J. Saudi Chem. Soc. 2018, 22, 405-415. [CrossRef]

50. Luo, L.; Liang, Y.; Erichsen, E.S.; Anwander, R. Monodisperse mesoporous silica nanoparticles of distinct topology. J. Colloid Interface Sci. 2017, 495, 84-93. [CrossRef] [PubMed]

51. Balas, F.; Manzano, M.; Horcajada, P.; Vallet-Regi, M. Confinement and controlled release of bisphosphonates on ordered mesoporous silica-based materials. J. Am. Chem. Soc. 2006, 128, 8116-8117. [CrossRef]

52. Ding, Y.; Tang, S.; Yu, B.; Yan, Y.; Li, H.; Wei, J.; Su, J. In Vitro degradability, bioactivity and primary cell responses to bone cements containing mesoporous magnesium-calcium silicate and calcium sulfate for bone regeneration. J. R. Soc. Interface 2015, 12. [CrossRef] 